\title{
DEVELOPMENT OF ANODIC STRIPPING VOLTAMMETRY FOR THE DETERMINATION OF PALLADIUM IN HIGH LEVEL NUCLEAR WASTE
}

\author{
T. K. BHARDWAJ ${ }^{1 *}$, H. S. SHARMA ${ }^{2 a}$, P. C. JAIN ${ }^{3 a}$, and S. K. AGGARWAL ${ }^{2}$ \\ ${ }^{1}$ Department of Nuclear Engineering, North Carolina State University \\ Raleigh, NC 27695, USA \\ ${ }^{2}$ Fuel Chemistry Division, Bhabha Atomic Research Centre \\ Mumbai 400085, India \\ ${ }^{3}$ Department of Chemistry, Meerut College \\ Meerut 250001, India \\ "Corresponding author. E-mail : tkbhardw@ncsu.edu
}

Received November 04, 2011

Accepted for Publication February 27, 2012

Deposition potential, deposition time, square wave frequency, rotation speed of the rotating disc electrode, and palladium concentration were studied on a Glassy Carbon Electrode (GCE) in $0.01 \mathrm{M} \mathrm{HCl}$ for the determination of palladium in High Level Nuclear Waste (HLNW) by anodic stripping voltammetry. Experimental conditions were optimized for the determination of palladium at two different, $10^{-8}$ and $10^{-7} \mathrm{M}$, levels. Error and standard deviation of this method were under $1 \%$ for all palladium standard solutions. The developed technique was successfully applied as a subsidiary method for the determination of palladium in simulated high level nuclear waste with very good precision and high accuracy (under $1 \%$ error and standard deviation).

KEYWORDS : Anodic Stripping Voltammetry, Determination of Palladium, High Level Nuclear Waste

\section{INTRODUCTION}

Palladium is a precious metal with high melting point, which has important catalytic and corrosion resistant properties. It is used in electrical [1], electrochemical [24], dental [5,6], jewelry [7], catalytic [8,9], and nuclear medicine [10] applications. In nuclear field, palladium is used for the purification and storage of radioactive tritium [11-14], and for the coating of Zircaloy cladding materials to improve their oxidation resistance property [15]. It is also used for the applications of experimental fusion [16] and high temperature gas cooled reactor (HTGR).

Palladium is produced as a fission product in nuclear fission process, and is associated with the reprocessing of high level nuclear waste [18]. In view of its limited occurrence in nature, and to meet the increasing demand, there is an emergent interest in its recovery from the high level nuclear waste as an alternative source $[19,20]$. Depending upon the burn-up of the fuel, reactor type, and reprocessing flow sheet, the expected amount of palladium

${ }^{\mathrm{a}}$ Retired in high level nuclear waste can be in 100-500 ppm range.

Electrochemical techniques have an important place in nuclear research. They are used for the study of nuclear materials [21], performance of zirconium at elevated temperature and pressure [22], behavior of stainless steel in PWR primary coolant conditions [23], and for the prediction of $\mathrm{UO}_{2}$ nuclear fuel dissolution rate under waste disposal conditions. Application of electroanalytical techniques for the determination of nuclear materials can also provide an interesting alternative over the traditional spectroscopic methods [24]. Electrochemical techniques offer several advantages over spectroscopic techniques. The cost of instrumentation is relatively low, thus inexpensive [25], and some of these techniques like stripping voltammetry are highly sensitive [26] and selective which can be used up to ppm and ppb level determinations [27]. Therefore, stripping voltammetry is a promising technique for the determination of palladium in high level nuclear waste since dealing with the least amount of nuclear materials is also important because of the radioactivity issue [28].

During the optimization of experimental conditions 
(results will be published elsewhere), $0.01 \mathrm{M} \mathrm{HCl}$ was observed to be the most suitable medium for the determination of palladium by Anodic Stripping Voltammetry (ASV). The deposition and reversible oxidation process of palladium on Glassy Carbon Electrode (GCE) in 0.01 $\mathrm{M} \mathrm{HCl}$ make Anodic Stripping Voltammetry a potentially attractive approach for its trace quantization from the high level nuclear waste. Thus, the efforts were made to develop this method in $0.01 \mathrm{M} \mathrm{HCl}$. Glassy carbon, a vitreous form of isotropic carbon, was preferred as a substrate for palladium deposition because of its mechanical strength, electrochemical inertness, defect free surface, and wide potential window [29].

\section{EXPERIMENTAL}

\subsection{Instrumentation}

Electrochemical analyzer PG Stat-30, from Micro Devices Metrohm, coupled with three-electrode voltammetric cell was used in present studies. Glassy carbon disc of $4 \mathrm{~mm}$ diameter as working, glassy carbon rod of $2 \mathrm{~mm}$ diameter as counter, and saturated calomel as reference electrode were used in voltammetric cell. Glassy carbon working electrode was polished to a mirror finish with 0.5 and $0.05 \mu$ alumina slurry before all experiments. All the voltammograms were automatically plotted by General Purpose Electrochemical Software.

\subsection{Reagents}

Preparation of palladium chloride $\left(\mathrm{PdCl}_{2}\right)$ stock solution, and its standardization are discussed elsewhere [30]. Synthetic sample concentrations of palladium were acquired by spiking the voltammetric cell with appropriate volume of this stock solution.

$\mathrm{HCl}$, Alpha Benzoin Oxime (ABO), and Solvesso100 used were of AR grade. Argon gas of high purity, Iolar grade-2, having less than 4 ppm oxygen was purged in electrolyte solution for ten minutes prior to the experiments. All potentials referred in the text are with reference to Saturated Calomel Electrode (SCE).

\subsection{Simulated High Level Nuclear Waste (HLNW)}

Simulated high level nuclear waste was occurred from the Fuel Reprocessing Division of Bhabha Atomic Research Centre, India, and used in studies as received. The concentration of various metal ions in simulated high level nuclear waste (nitrate salts preferred) is given in table 1. Metal powder, metal oxide, and chloride salts were employed in the absence of nitrate salts. Each of them was dissolved separately in hot conc. nitric acid before their addition to one another. Acidity of the simulated HLNW was ascertained by alkalimetry in the presence of neutral saturated $\mathrm{K}_{2} \mathrm{C}_{2} \mathrm{O}_{4}$ solution. The overall acidity of simulated HLNW was adjusted by evaporating the solution to near dryness, and then adding $3 \mathrm{M} \mathrm{HNO}_{3}$. The concentration of fission products in simulated HLNW corresponds to the burn up of $6500 \mathrm{MWd} / \mathrm{Te}$ of natural $\mathrm{UO}_{2}$ in a Pressurized Heavy Water Reactor (PHWR). Approximately 800 liters of HLNW is generated/tonne of the spent nuclear fuel reprocessed.

\subsection{Solvent Extraction Experiments}

Palladium was extracted from the high level nuclear waste by solvent extraction method [31]. Known amounts of synthetic samples were transferred to a $15 \mathrm{ml}$ equilibration tube, followed by $2 \mathrm{ml}$ of $0.01 \mathrm{M}$ Alpha Benzoin Oxime (ABO) in Solvesso-100. The equilibration tube was shaken for 5 minutes, and followed by the addition of 2 $\mathrm{ml}$ thiourea. In a next step, equilibration tube was shaken for another 5 minutes, and allowed to stand ( $5 \mathrm{~min})$ for the phase separation. After this, $2 \mathrm{ml}$ of $60 \% \mathrm{HClO}_{4}$ was added to equilibration tube, and evaporated to dryness. This step was repeated two times. Then, the aqueous phase was prepared in $100 \mu \mathrm{l}$ of $3 \mathrm{M} \mathrm{HNO}_{3}$. The aqueous phase was transferred to polarographic cell, and followed by the addition of supporting electrolyte solution $(\mathrm{HCl})$.

Table 1. Composition of Simulated High Level Nuclear Waste (HLNW) for a Pressurized Heavy Water Reactor (PHWR)

\begin{tabular}{|c|c|c|c|}
\hline Constituent & Conc. (mg/L) & Constituent & Conc. (mg/L) \\
\hline $\mathrm{Se}^{\mathrm{b}}$ & 12.3 & $\mathrm{Rb}^{\mathrm{a}}$ & 74.5 \\
\hline $\mathrm{Sr}^{\mathrm{a}}$ & 186.3 & $Y^{d}$ & 99 \\
\hline $\mathrm{Zr}^{\mathrm{a}}$ & 771.3 & $\mathrm{Mo}^{\mathrm{b}}$ & 731.3 \\
\hline $\mathrm{Ru}^{\mathrm{d}}$ & 463.8 & $\mathrm{Co}^{\mathrm{a}^{* *}}$ & 127.5 \\
\hline $\mathrm{Pd}^{\mathrm{d}}$ & 267.5 & $\mathrm{Ag}^{\mathrm{a}}$ & 18.6 \\
\hline $\mathrm{Cd}^{\mathrm{a}}$ & 16.3 & $\mathrm{Sn}^{\mathrm{b}}$ & 15.6 \\
\hline $\mathrm{Sb}^{\mathrm{b}}$ & 4.7 & $\mathrm{Te}^{\mathrm{b}}$ & 102.8 \\
\hline $\mathrm{Cs}^{\mathrm{a}}$ & 543.8 & $\mathrm{Ba}^{\mathrm{a}}$ & 308.8 \\
\hline $\mathrm{La}^{\mathrm{d}^{*}}$ & 263.8 & $\mathrm{Ce}^{\mathrm{a}}$ & 532.5 \\
\hline $\mathrm{Nd}^{\mathrm{c}}$ & 862.5 & $\mathrm{Eu}^{\mathrm{c}}$ & 22.6 \\
\hline $\mathrm{Sm}^{\mathrm{c}}$ & 163.8 & $\mathrm{Fe}^{\mathrm{b}}$ & 500 \\
\hline $\mathrm{Na}^{\mathrm{a}}$ & 3000 & $\mathrm{Cr}^{\mathrm{a}}$ & 100 \\
\hline $\mathrm{Ni}^{\mathrm{a}}$ & 100 & $\mathrm{Mn}^{\mathrm{a}^{* * * *}}$ & 181.3 \\
\hline $\mathrm{U}^{\mathrm{a}}$ & 20000 & $\mathrm{~Tb}^{\mathrm{c}}$ & 5.0 \\
\hline $\operatorname{Pr}^{\mathrm{c}}$ & 243.8 & $D y^{c}$ & \\
\hline $\mathrm{Gd}^{\mathrm{c}}$ & 165 & & \\
\hline
\end{tabular}

a: Nitrate salt; ${ }^{\text {b. }}$ : Metal powder; ${ }^{\text {c: }}$ Oxide and ${ }^{\text {d: }}$ Chloride salt; ${ }^{*}$ : at place of $\mathrm{Pm} ;{ }^{* *}$ : at place of $\mathrm{Rh}$ and ${ }^{* * *}$ : at place of Tc. 


\subsection{Procedure}

$15 \mathrm{ml}$ of $0.01 \mathrm{M}$ supporting electrolyte was placed in a dry cell, and degassed for 5 minutes before the measurements. This solution was then spiked with the corresponding stock solution of palladium to get a net concentration of $5 \mu \mathrm{M}$ in the cell.

Palladium was preconcentrated on GCE at different, from 0.1 to $-0.7 \mathrm{~V}$, deposition potentials, for different times, from 100 to 600 seconds, with different solution stirring rates. The stripping of palladium was carried out from 0.25 to $0.75 \mathrm{~V}$ in square wave mode of different frequencies, $10-70 \mathrm{~Hz}$, to optimize the experimental conditions for analysis.

\section{RESULTS AND DISCUSSION}

\subsection{Effect of Deposition Potential}

The effect of deposition potential on palladium stripping peak current was studied in details. Cyclic voltammetric studies of $1 \mathrm{mM} \mathrm{Pd(II)} \mathrm{on} \mathrm{GCE} \mathrm{in} 0.01 \mathrm{M}$ $\mathrm{HCl}$ showed that cathodic peak potential $\left(\mathrm{E}_{\mathrm{pc}}\right)$ of palladium reduction is $41 \mathrm{mV}$. Hence, deposition potentials from 0.1 to $-0.7 \mathrm{~V}$ were studied for the proper accumulation of palladium, and least interference of hydrogen evolution at $5 \mu \mathrm{M}$ palladium concentration, 200 seconds deposition time, $1000 \mathrm{rpm}$ electrode rotation speed, and $50 \mathrm{~Hz}$ squarewave frequency. The effect of various deposition potentials on stripping peak current is shown in figure 1. At $0.1 \mathrm{~V}$, a very small, $1 \mu \mathrm{A}$, stripping current was observed because palladium deposits very slowly at this potential. However, an increased, $4.62 \mu \mathrm{A}$, stripping current was observed at $-0.4 \mathrm{~V}$. Further increase in deposition potential, up to -0.7

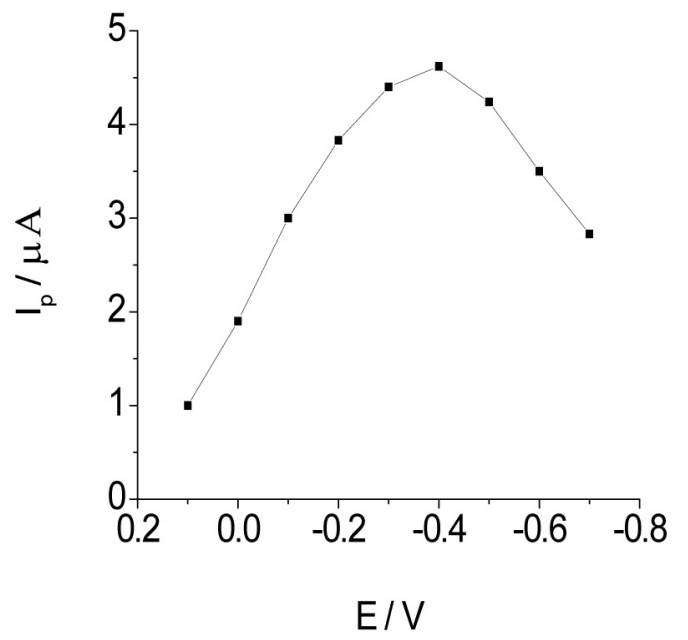

Fig. 1. Effect of Different Deposition Potentials (0.1, 0.0, -0.1, $-0.2,-0.3,-0.4,-0.5,-0.6 \&-0.7$ V) on Palladium Stripping Current.
$\mathrm{V}$, showed a decrease in stripping current to $2.83 \mu \mathrm{A}$, which is attributed to hydrogen evolution at GCE surface.

\subsection{Effect of Palladium Concentration}

The effect of palladium concentration on stripping current was studied at two different sub- $\mu \mathrm{M}$ levels at constant $-0.4 \mathrm{~V}$ deposition potential, 200 seconds deposition time, $1000 \mathrm{rpm}$ electrode rotation speed, and $50 \mathrm{~Hz}$ square-wave frequency. At $10^{-7} \mathrm{M}$ level, an increase in stripping current was observed from 0.76 to $4.21 \mu \mathrm{A}$ with the increasing palladium concentration. The increase in stripping current at $10^{-8} \mathrm{M}$ level was observed from 0.23 to $1.98 \mu \mathrm{A}$. The efforts to detect palladium concentration as low as $10^{-9} \mathrm{M}$ level were unsuccessful in present experimental conditions. A linear relationship with regression coefficient of 0.99 was observed between the stripping current and palladium concentration. The results are shown in figure 2.

\subsection{Effect of Deposition Time}

The effect of deposition time $\left(\mathrm{t}_{\mathrm{d}}\right)$ on palladium stripping current was studied from 100 to 600 seconds at constant $0.4 \mathrm{~V}$ deposition potential, $5 \mu \mathrm{M}$ palladium concentration, 200 seconds deposition time, $1000 \mathrm{rpm}$ electrode rotation speed, and $50 \mathrm{~Hz}$ square-wave frequency. Stripping current showed a linear relation with the deposition time from 100 to 400 seconds. However, for the deposition times more than 400 seconds, stripping current started to become stabilized.

Our cyclic voltammetric studies (detailed results will be published elsewhere) show that once the deposition of palladium starts, a GC/palladium surface is formed on GCE. This newly formed GC/palladium surface results in a negative shift, from -85 to $-115 \mathrm{mV}$, of the deposition

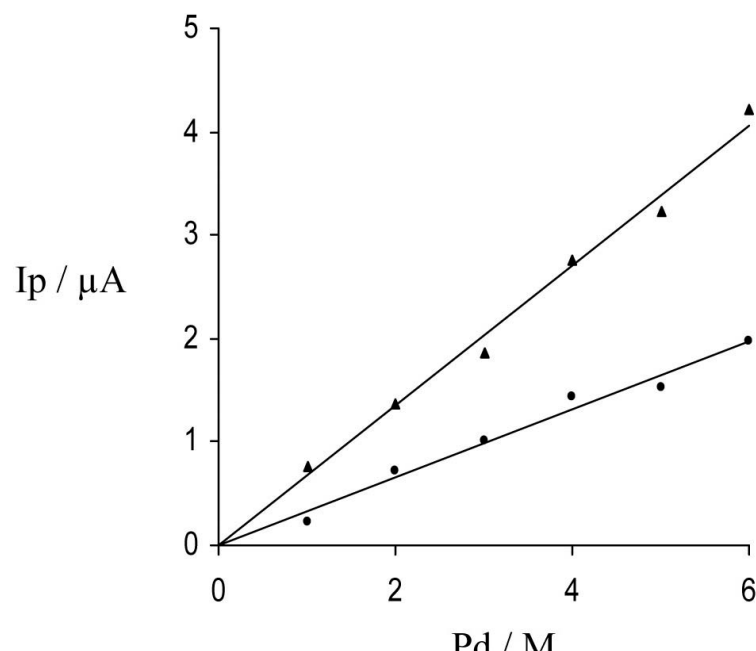

Fig. 2. Effect of Palladium Concentration $(\bullet) \times 10^{-8}(\mathbf{4}) \times 10^{-7} \mathrm{M}$ on Palladium Stripping Current. 


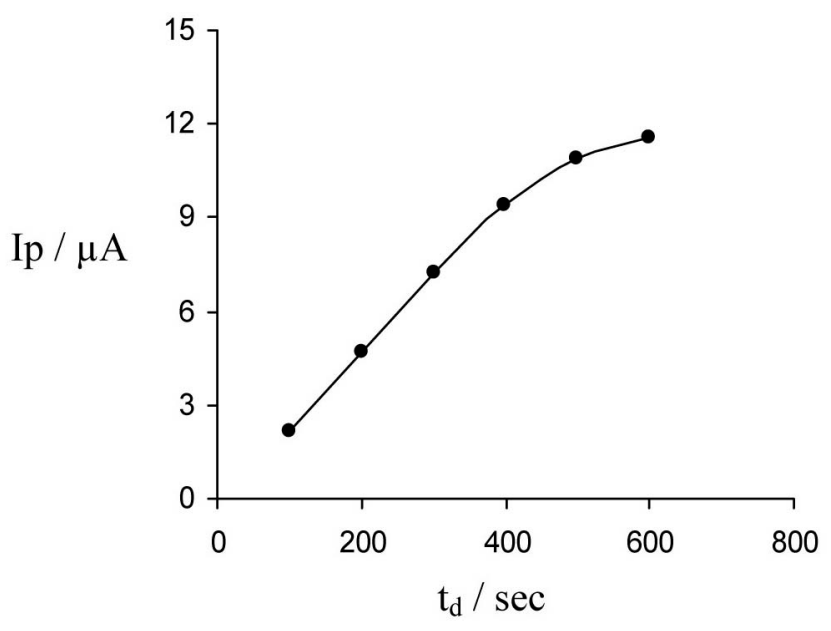

Fig. 3. Effect of Deposition Time from 100-600 Seconds on Palladium Stripping Current.

potential, and thus the further deposition of palladium on GCE becomes difficult with the increasing time. The evolution, adsorption, and absorption of hydrogen on GC/Pd surface are proportional to the deposition time [32]. Therefore, the interference of $\mathrm{H}+$ ions also increases with the increasing deposition time, which competes with palladium deposition. Furthermore, in each stripping step, a certain amount of the whole palladium deposited remains unstrapped. The unstrapped amount of palladium increases with the increasing deposition time [32], which results in the curvature of plot. The results of the relationship of stripping current with deposition time are shown in figure 3.

\subsection{Effect of Rotation Speed}

The effect of rotation speed of the electrode $(\mathrm{N})$ on palladium stripping current was studied from 500 to 1000 rpm at constant $-0.4 \mathrm{~V}$ deposition potential, $5 \mu \mathrm{M}$ palladium concentration, 200 seconds deposition time, and $50 \mathrm{~Hz}$ square-wave frequency. The stripping current increases linearly with the rotational speed of the electrode. The results of the study of the effect of the rotation speed on stripping current are show in figure 4 . The regression coefficient of the plot was 0.98 , however, the slope of the plot was only $0.034 \mu \mathrm{A} / \mathrm{rpm}^{1 / 2}$ which indicates relatively a small increase in the deposition of palladium with increasing rotation speed.

\subsection{Effect of Square Wave Frequency}

The effect of square wave frequency on palladium stripping current was studied from 10 to $70 \mathrm{~Hz}$ at constant $-0.4 \mathrm{~V}$ deposition potential, $5 \mu \mathrm{M}$ palladium concentration, 200 seconds deposition time, and $1000 \mathrm{rpm}$ electrode rotation speed. The stripping current increased from 2.3 to $5.66 \mu \mathrm{A}$ with an increase in square wave frequency from 10 to $70 \mathrm{~Hz}$. However, an increase in background was

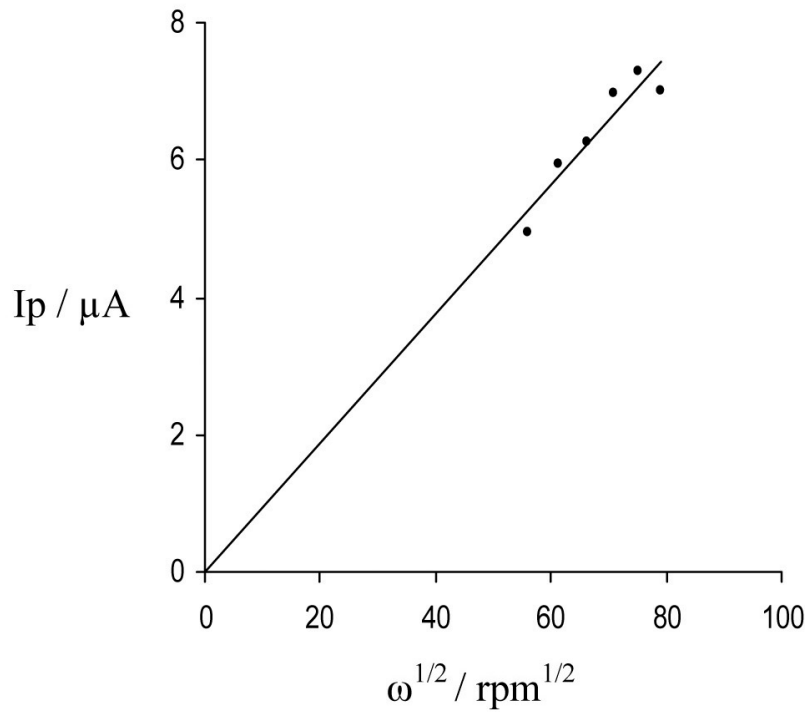

Fig. 4. Effect of Rotation Speed from 500-1000 Rpm on Palladium Stripping Current.

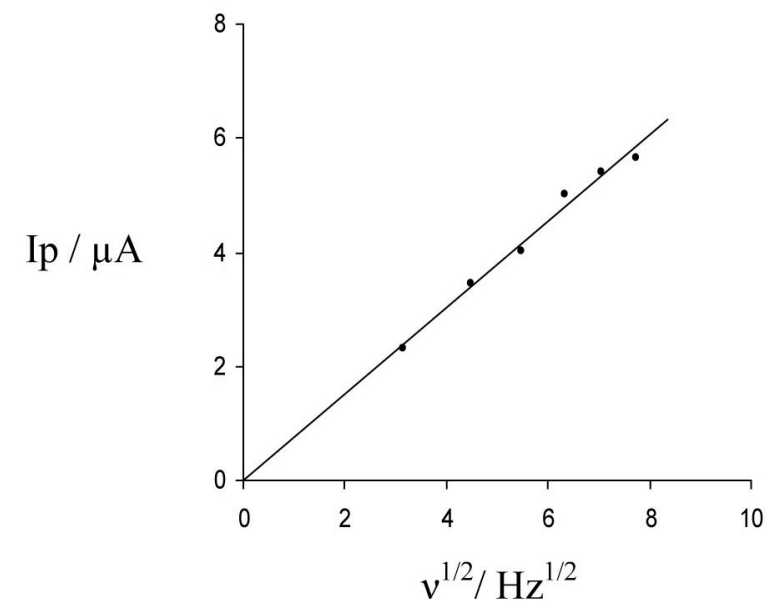

Fig. 5. Effect of Square-wave Frequency from 10-70 Hz on Palladium Stripping Current.

also observed at higher frequencies. A linear relationship was observed between the stripping current and the square root of square wave frequency. The results are shown in figure 5. Because of the increasing background and small, $0.75 \mu \mathrm{A} / \mathrm{rpm}^{1 / 2}$, slope of the plot, a frequency of $50 \mathrm{~Hz}$ was found suitable for the determination of palladium in high level nuclear waste.

\section{DETERMINATION OF PALLADIUM}

The developed methodology was applied for the determination of palladium in simulated high level nuclear 
Table 2. Determination of Palladium in Synthetic Sample Solutions

\begin{tabular}{c|c|c|c|c}
\hline Palladium in sample $(\mathrm{M})$ & No. of determinations & Mean palladium Conc. Detected $(\mathrm{M})$ & Mean error $(\%)$ & $\%$ SD \\
\hline $5.00 \times 10^{-7}$ & 5 & $4.94 \times 10^{-7}$ & -1.24 & 0.90 \\
\hline $2.00 \times 10^{-6}$ & 5 & $1.98 \times 10^{-6}$ & -1.10 & 0.66 \\
\hline $5.00 \times 10^{-6}$ & 5 & $4.95 \times 10^{-6}$ & -0.96 & 0.76 \\
\hline
\end{tabular}

waste after the optimization of experimental conditions. Palladium was deposited on GCE at $-0.4 \mathrm{~V}$ for 200 seconds with constant $1000 \mathrm{rpm}$ solution stirring. The stripping of palladium was carried out from 0.25 to $0.75 \mathrm{~V}$ in square wave mode of $50 \mathrm{~Hz}$ frequency after a five seconds rest period. Palladium content in all samples was determined from a standard addition procedure.

\subsection{In synthetic Palladium Samples}

The accuracy and precision of this method were assessed by analyzing synthetic samples of palladium(II) solutions in $0.01 \mathrm{M} \mathrm{HCl}$ at three different, $5 \times 10^{-7}, 2 \times 10^{-6}$, and $5 \times 10^{-6} \mathrm{M}$ concentration levels. Single and multiple (in few determinations) addition methods were applied for the determination of palladium. The relative mean error in experimental results with single standard addition procedure was around $1 \%$ for all concentration levels. However, the multiple standard addition procedure gave more error in results. The precision obtained at all concentration levels was under $1 \%$ SD which is very good for analysis. The results of the determination of palladium in synthetic samples are shown in table 2.

\subsection{In Simulated High Level Nuclear Waste (HLNW)}

Palladium content in simulated high level nuclear waste was determined to be $264.9 \mathrm{mg} / \mathrm{L}$ with this method after solvent extraction. Results presented in table 3 show that this method gives very good precision $(0.63 \% \mathrm{SD})$ and high, more than $99 \%$, accuracy.

\section{CONCLUSIONS}

An Anodic Stripping Voltammetric method was developed for the determination of palladium in high level nuclear waste. The developed method was applied successfully for the determination of palladium in simulated high level nuclear waste with very good precision and high accuracy. This method is highly sensitivity, selective, and accurate, which give very precise results.

\section{ACKNOWLEDGEMENTS}

Authors are sincerely thankful to Dr. V. Venugopal, Director, Radiochemistry \& Isotope Group, and H. S. Kamath, Director, Nuclear Fuels Group, BARC for their
Table 3. Determination of Palladium in Simulated High Level Nuclear Waste

\begin{tabular}{c|c|c|c|c}
\hline Sample no. & $\begin{array}{c}\text { Pd detected } \\
(\mathrm{mg} / \mathrm{L})\end{array}$ & $\begin{array}{c}\text { Mean Pd detected } \\
(\mathrm{mg} / \mathrm{L})\end{array}$ & $\begin{array}{c}\text { Average \% } \\
\text { error }\end{array}$ & $\%$ SD \\
\hline 1 & 265.8 & & & \\
\cline { 1 - 2 } 2 & 265.3 & & & \\
\cline { 1 - 2 } 3 & 262.1 & 264.9 & -0.99 & \multirow{2}{*}{0.63} \\
\cline { 1 - 2 } 4 & 266.4 & & & \\
\cline { 1 - 2 } 5 & 264.7 & & & \\
\hline
\end{tabular}

constant encouragement, support and interest in this work. Special thanks to Dr. P.S. Dhami, Fuel Reprocessing Division, BARC for providing simulated HLNW, reagents for palladium separation, and important technical discussion during the course of this work.

\section{REFERENCES}

[1] Y. B. Kudasov and A.S. Korshunov, "Surface ferromagnetism of palladium induced by strong electric field," Physics Letters A, 364, 348-351 (2007).

[2] A. I. Matesanz, J. Mosa, I. García, and C. Pastor, P. Souza, "Synthesis, characterization, crystal structure and electrochemistry of a novel palladium(II) binuclear complex containing 1,2,4-triazole bis(4-phenylthiosemicarbazone) bridges," Inorganic Chemistry Communications, 7, 756759 (2004).

[ 3 ] G. Zotti, G. Pilloni, P. Rigo, and M. Martelli, "Electrochemistry of coordination compounds: Part XVII. Electron transfer properties in nickel(II), palladium(II) and platinum(II) complexes with hybrid bidentate ligands containing phosphorus and nitrogen or sulfur donor atoms," Journal of Electroanalytical Chemistry and Interfacial Electrochemistry, 124, 277-284 (1981).

[4] L.D. Burke and L.C. Nagle, "Anomalous electrochemical behaviour of palladium in aqueous solution," Journal of Electroanalytical Chemistry, 461, 52-64 (1999).

[ 5 ] W.H. Guo, W.A. Brantley, W.A.T. Clark, J.Z. Xiao, and E. Papazoglou, "Transmission electron microscopic studies of deformed high-palladium dental alloys," Dental Materials, 19, 334-340 (2003).

[6] A.L. Neme, W.C. Wagner, and W.J. O'Brien, "Effects of palladium addition on emission of mercury vapor from dental amalgam," Dental Materials, 15, 382-389 (1999). 
[ 7 ] M.Á. Ontalba Salamanca, B. Gómez-Tubío, I. OrtegaFeliu, M.Á. Respaldiza, M. Luisa de la Bandera, G. Ovejero Zappino, A. Bouzas, and A. Gómez-Morón, "Externalbeam PIXE spectrometry for the study of Punic jewellery (SW Spain): The geographical provenance of the palladiumbearing gold," Nuclear Instruments and Methods in Physics Research Section B: Beam Interactions with Materials and Atoms, 249, 622-627 (2006).

[ 8 ] L. S. Escandón, S. Ordóñez, A. Vega, and Fernando V. Díez, "Oxidation of methane over palladium catalysts: effect of the support," Chemosphere, 58, 9-17 (2005).

[9] L. M. Neal, D. Hernandez, and H. E. Hagelin-Weaver, "Effects of nanoparticle and porous metal oxide supports on the activity of palladium catalysts in the oxidative coupling of 4-methylpyridine," Journal of Molecular Catalysis A: Chemical, 307, 29-36 (2009).

[10] M. Neves, F. Waerenborgh, and L. Patricio, "Palladium109 and holmium-166 potential radionuclides for synoviotherapy_radiation absorbed dose calculations," International Journal of Radiation Applications and Instrumentation. Part A. Applied Radiation and Isotopes, 38, 745-749 (1987).

[11] A. Fabre, B. Decamps, E. Finot, J.M. Penisson, J. Demoment, S. Thiebaut, S. Contreras, and A. Percheron-Guegan, "On the correlation between mechanical and TEM studies of the aging of palladium during tritium storage," Journal of Nuclear Materials, 342, 101-107 (2005).

[12] J.A. Emig, R.G. Garza, L.D. Christensen, P.R. Coronado, and P.C. Souers, "Helium release from 19-year-old palladium tritide," Journal of Nuclear Materials, 187, 209-214 (1992).

[13] S. Thiébaut, B. Décamps, J.M. Pénisson, B. Limacher, A. Percheron Guégan, "TEM study of the aging of palladiumbased alloys during tritium storage," Journal of Nuclear Materials, 277, 217-225 (2000).

[14] L. Wenhua, S. Cansheng, L. Xuejian, 'Purification of hydrogen isotopes using palladium molecular sieve," Journal of Nuclear Materials, 329, 1361-1364 (2004).

[15] G.A. Eloff, C.J. Greyling, P.E. Viljoen, "Improvement in oxidation resistance of Zircaloy-4 by surface alloying with a thin layer of palladium," Journal of Nuclear Materials, 202, 239-244 (1993).

[16] I. Takagi, K. Moritani, H. Moriyama, "Asymmetric surface recombination of hydrogen on palladium exposed to plasma," Journal of Nuclear Materials, 313, 102-106 (2003).

[17] K. Minato, T. Ogawa, S. Kashimura, K. Fukuda, M. Shimizu, Y. Tayama, I. Takahashi, "Fission product palladiumsilicon carbide interaction in htgr fuel particles,' Journal of Nuclear Materials, 172 184-196 (1990).

[18] H. J. Ache et. al., "Feasibility of seperation and utilization of Ruthunium, Rhodium and Palladium from high level wastes," Technical Report series No 308, IAEA, Viena (1989).

[19] H. Bokelund, C. Apostolidis, J.-P. Glatz, "Recovery and chemical purification of actinides at JRC, Karlsruhe," Journal of Nuclear Materials, 166, 181-188 (1989).

[20] Z. Dlouhý, Studies in Environmental Science, v. 15, Elsevier, New York, 1982.

[21] S.A. Kuznetsov, M. Gaune-Escard, "Electrochemical transient techniques for study of the electrochemistry and thermodynamics of nuclear materials in molten salts," Journal of Nuclear Materials, 389, 108-114 (2009).

[22] Y. Chen, M. Urquidi-Macdonald, D. D. Macdonald, "The electrochemistry of zirconium in aqueous solutions at elevated temperatures and pressures," Journal of Nuclear Materials, 348, 133-147 (2006).

[23] B. Muzeau, S. Perrin, C. Corbel, D. Simon, D. Feron, "Electrochemical behaviour of stainless steel in PWR primary coolant conditions: Effects of radiolysis," Journal of Nuclear Materials, 419, 241-247 (2011).

[24] T.K. Bhardwaj, H.S. Sharma, S.K. Aggarwal, "Development of anodic stripping voltammetry for determination of gallium in U-Ga alloy," Journal of Nuclear Materials, 360, 215221 (2007).

[25] A. M. Bond, P. J. Mahon, J. Schiewe, V. Vicente-Beckett, "An inexpensive and renewable pencil electrode for use in field-based stripping voltammetry," Analytica Chimica Acta, 345, 67-74 (1997).

[26] S. Abbasi, A. Bahiraei, F. Abbasai, "A highly sensitive method for simultaneous determination of ultra trace levels of copper and cadmium in food and water samples with luminol as a chelating agent by adsorptive stripping voltammetry," Food Chemistry, 129, 1274-1280 (2011).

[27] M. J. G. González, O. D. Renedo, M. Asunción A. Lomillo, M. Julia A. Martínez, "Determination of gallium by adsorptive stripping voltammetry," Talanta, 62, 457-462 (2004).

[28] K. C. Marsden, B. Pesic, "Evaluation of the Electrochemical Behavior of $\mathrm{CeCl} 3$ in Molten LiCl-KCl Eutectic Utilizing Metallic Ce as an Anode," J. Electrochem. Soc., 158, 111120 (2011).

[29] Y. Li, X. Lin, "Simultaneous electroanalysis of dopamine, ascorbic acid and uric acid by poly (vinyl alcohol) covalently modified glassy carbon electrode," "Sensors and Actuators B: Chemical," 115, 134-139 (2006).

[30] V.I. Birss, V.H. Beck, A.J. Zhang, P. Vanýsek, "Properties of thin, hydrous Pd oxide films,' Journal of Electroanalytical Chemistry, 429, 175-184 (1997).

[31] A. Dakshinamoorthy, P.S. Dhami, P.W. Naik, N.L. Dudwadkar, S.K. Munshi, P.K. Dey, V. Venugopal, "Separation of palladium from high level liquid waste of PUREX origin by solvent extraction and precipitation methods using oximes," Desalination, 232, 26-36 (2008).

[32] G. East, P. Cofre, "Determination of gallium by squarewave voltammetry anodic stripping, based on the electrocatalytic action of $2,2^{\prime}$ - bipyridine in dimethylsulphoxide: Comparison with an aqueous $\mathrm{NaSCN} / \mathrm{NaClO}_{4}$ electrolyte," Talanta, 40 1273-1281 (1993). 